Marta Bodys

Uniwersytet Wrocławski

\title{
Komunikacja liderów polskich partii politycznych w mediach społecznościowych w okresie pełnego cyklu wyborczego w latach 2014-2015
}

\author{
DOI: $10.19195 / 1643-0328.23 .11$
}

Słowa kluczowe: media społecznościowe, liderzy polityczni, partie polityczne, kampania wyborcza

\section{Wprowadzenie}

Komunikowanie polityczne to wycinek komunikowania społecznego dotyczący tego, co polityczne (w szerokim rozumieniu terminu „polityka”), uwarunkowany ściśle powiązanymi z sobą czynnikami, wpływającymi na kształtowanie się komunikowania politycznego, szczególnie modernizację, przemiany i saturację technologiczną społeczeństwa, personalizację i profesjonalizację. Obejmuje konkretną przestrzeń komunikacyjną i zbiorowość ludzką. Jego uczestnikami są (1) aktorzy polityczni, (2) obywatele i (3) media masowe, choć wraz z rozwojem technologii komunikacyjnych, szczególnie Internetu, stosunki między nimi uległy przemianie. Nowoczesne komunikowanie polityczne nastawione jest na dwukierunkowość zachodzącą pomiędzy wszystkimi trzema uczestnikami procesu komunikowania. Za sprawą mediów społecznościowych rośnie też intensywność bezpośrednich, wcześniej przypadkowych, relacji aktorów politycznych z obywatelami.

Badania nad komunikacją polityczną w Internecie intensywnie się rozwijają, stale jednak wymagają empirycznych analiz i komparatystyki pozwalających na wyciąganie wniosków odnośnie do tego, jak przebiega komunikacja aktorów politycznych z wyborcami, jakie są relacje między różnymi rodzajami aktorów politycznych, jaki wpływ na intensywność komunikacji politycznej mają różne okresy w cyklu wyborczym. Badania nad komunikacją internetową polskich aktorów politycznych skupiają się obecnie przede wszystkim na analizie pojedynczych elekcji lub wybranego aspektu komunikowania politycznego $\mathrm{w}$ Internecie. Zagadnienia te $\mathrm{w}$ swoich pracach podejmują: Jan Garlicki, Daniel Mider, Marek Jeziński, Łukasz Przybysz, Michał Jacuński, Dominik 
Batorski, Agnieszka Łada. Dla niniejszego artykułu istotne są też prace omawiające komunikowanie polityczne $\mathrm{w}$ mediach społecznościowych z perspektywy marketingowej autorstwa Wojciecha Cwaliny czy Sergiusza Trzeciaka.

\section{Przedmiot i metoda analizy}

Artykuł przedstawia wyniki badania komunikacji politycznej liderów polskich partii politycznych, które można uznać za relewantne, w trakcie ostatniego, pełnego cyklu wyborczego w latach 2014-2015. Na przestrzeni tych 2 lat odbyły się wszystkie rodzaje ogólnopolskich elekcji: wybory do Parlamentu Europejskiego (PE) w lutym 2014, wybory samorządowe w listopadzie 2014, wybory prezydenckie w maju 2015 oraz wybory parlamentarne w październiku 2015. Ich ramy czasowe należy określić szerzej niż od momentu ogłoszenia wyborów do dnia głosowania. Na potrzeby niniejszej analizy przyjmuje się, że:

a) kampania przed wyborami do PE obejmuje okres od 1 lutego do 25 maja 2014,

b) kampania przed wyborami samorządowymi obejmuje okres od 1 sierpnia do 16 listopada 2014,

c) kampania przed wyborami prezydenckimi obejmuje okres od 1 lutego do 24 maja 2015 ,

d) kampania przed wyborami parlamentarnymi obejmuje okres od 1 lipca do 25 października 2015.

Do analizy wybrani zostali faktyczni liderzy (przewodniczący, prezes itp.) partii politycznych, które w ostatnich czterech ogólnopolskich elekcjach można uznać za relewantne - tzn. takich, które przynajmniej dwa razy brały udział w wyborach, zgłaszając listy wyborcze w całym kraju, i których kandydatom przynajmniej raz udało się zdobyć mandaty do odpowiednich organów kolegialnych. W przypadku koalicji pod uwagę wzięte zostały największe partie polityczne wchodzące w ich skład. Lidera partii politycznej na potrzeby tej pracy definiuje się jako osobę stojącą na czele partii politycznej, pełniącą funkcje kierownicze - prezesa lub przewodniczącego, nominowanego najczęściej w wyniku wyborów wewnętrznych w ugrupowaniu. Pod uwagę brani są formalni liderzy, nie zaś kandydaci wystawiani przez ugrupowanie na listach wyborczych, szczególnie tzw. lokomotywy wyborcze. I tak analizowana jest komunikacja w Internecie:

a) liderów Platformy Obywatelskiej (PO) - Donalda Tuska i Ewy Kopacz,

b) lidera Prawa i Sprawiedliwości (PiS) - Jarosława Kaczyńskiego (oraz dodatkowo, co jest uzasadnione w dalszej części pracy, Beaty Szydło i Andrzeja Dudy),

c) lidera Polskiego Stronnictwa Ludowego (PSL) - Janusza Piechocińskiego,

d) lidera Sojuszu Lewicy Demokratycznej (SLD) - Leszka Millera,

e) lidera Kongresu Nowej Prawicy (KNP), Partii Wolność (KORWiN) - Janusza Korwina-Mikkego. 
Scharakteryzowana została również komunikacja liderów partii politycznych ${ }^{1}$ utworzonych przed wyborami parlamentarnymi w 2015 r., które mimo krótkiego okresu działalności uzyskały dobry wynik wyborczy, czyli ugrupowań: Partia Razem, .Nowoczesna i Kukiz'15.

Celem przeprowadzonych badań było uzyskanie odpowiedzi na pytania:

a) Jakie znaczenie ma Internet, szczególnie media społecznościowe, w komunikacji liderów partii politycznych?

b) Jakich narzędzi używają liderzy partii politycznych w komunikacji internetowej?

c) Jaki jest poziom i jakość aktywności liderów politycznych używających mediów społecznościowych?

d) Jaki jest poziom interakcji internautów z treściami publikowanymi przez liderów partii politycznych w Internecie?

e) Jaka jest relacja pomiędzy aktywnością partii politycznych a aktywnością ich liderów w mediach społecznościowych?

f) Jaka jest relacja pomiędzy popularnością liderów partii politycznych w mediach społecznościowych a wynikami wyborczymi partii politycznych?

Zadawane są one w celu weryfikacji następujących hipotez:

a) Liderzy polskich partii politycznych wykorzystują media społecznościowe mniej efektywnie niż partie polityczne, które reprezentują.

b) Internetowa komunikacja, szczególnie ta w mediach społecznościowych, nie ma dużego znaczenia dla liderów najważniejszych partii politycznych.

c) Liderzy partii politycznych do komunikacji w mediach społecznościowych używają najczęściej fanpage’a na Facebooku i do tego kanału komunikacji przywiązują największą wagę.

d) Komunikacja liderów partii politycznych w Internecie z punktu widzenia prowadzenia kampanii wyborczych przez ugrupowania polityczne odgrywa rolę drugorzędną.

e) Komunikacja liderów partii politycznych w Internecie pełni jedynie funkcję wspierającą, nie ma znaczącego wpływu na wynik wyborczy ugrupowania.

Do weryfikacji wskazanych hipotez badawczych wykorzystano podejście marketingowe i marketingowe narzędzia analizy skuteczności komunikacji internetowej. Praca pisana jest z perspektywy nie tylko badacza, ale i praktyka komunikacji. Podejście takie łączy metodę ilościową, pozwalającą na zamknięcie komunikacji internetowej w mediach społecznościowych w kategoriach mierzonych odpowiednią liczbą, jak opisany w dalszej części pracy wskaźnik SII, z metodą jakościową, dzięki której opisane zostały stosowane narzędzia komunikacyjne.

Do zebrania danych - historycznych wpisów z Twittera i Facebooka, dwóch najważniejszych kanałów komunikacji w mediach społecznościowych ${ }^{2}$ - zostało użyte na-

${ }^{1}$ Partia polityczna w niniejszej pracy jest rozumiana, zgodnie z definicją Ryszarda Herbuta, jako dowolna organizacja aktywna w sferze władzy politycznej, która uczestniczy w procesie wyborczym. Więcej w: Leksykon politologii, red. A. Antoszewski, R. Herbut, Wrocław 2004, s. 298.

${ }^{2}$ Ze względu na swoją popularność mierzoną liczbą użytkowników oraz stopniem możliwej do nawiązania interakcji z internautami. 
rzędzie NapoleonCat ${ }^{3}$. Umożliwiło ono zmierzenie poziomu aktywności fanów na fanpageach liderów partii politycznych. Narzędzie to na podstawie autorskiego algorytmu określa Social Interaction Index (dalej: SII), czyli wskaźnik liczbowy, który odzwierciedla aktywność internautów odwiedzających dany fanpage. Nie bierze on pod uwagę aktywności administratorów profilu, lecz liczbę komentarzy, postów, polubień i koreluje ją $\mathrm{z}$ wielkością strony (liczbą fanów). Im większy fanpage, tym intensywniejsza musi być aktywność fanów, by strona uzyskała dobry wynik SII. Im jest on wyższy, tym więcej interakcji z internautą zachodzi na fanpage $u^{4}$. Wysokość wskaźnika umożliwia porównanie aktywności na stronach poszczególnych polityków oraz wskazanie tych, którzy budzą największe zainteresowanie, a co za tym idzie - największą aktywność internautów, potencjalnych wyborców.

\section{Komunikacja liderów partii politycznych}

\section{Liderzy Platformy Obywatelskiej — Donald Tusk i Ewa Kopacz}

W analizowanym okresie na czele PO stało dwoje polityków - Donald Tusk oraz Ewa Kopacz, którzy jednocześnie pełnili funkcję Prezesa Rady Ministrów. Donald Tusk funkcję przewodniczącego PO pełnił od 1 czerwca 2003 do 8 listopada 2014, potem jego obowiązki przejęła Ewa Kopacz. Zastąpiła go ona również na stanowisku premiera, którym był do 22 września 2014. Zmiana ta związana była z objęciem przez Tuska stanowiska przewodniczącego Rady Europejskiej.

W trakcie badań opisywanych w niniejszym artykule analizowane były dwie ogólnopolskie elekcje obejmujące okres, w którym Donald Tusk był liderem PO (wybory do PE oraz wybory samorządowe), oraz dwie, w trakcie których była nim Ewa Kopacz (wybory prezydenckie i parlamentarne).

\section{Donald Tusk}

Aktywność Donalda Tuska w sieci ogranicza się do struktury partii, w której działa, lub funkcji, którą pełnił. Przekazy w jego imieniu były publikowane na Twitterze, fanpage’u (Facebook) czy stronie internetowej partii i Kancelarii Prezesa Rady Ministrów. Donald Tusk nie miał własnej strony internetowej. Domena www.donaldtusk.pl przekierowuje do oficjalnej strony PO.

W trakcie wyborów do PE i wyborów samorządowych jego indywidualna aktywność w Internecie skupiała się wyłącznie na komunikacji za pośrednictwem Twittera (@donaldtusk). Polityk nie miał oficjalnego profilu na Facebooku, Instagramie czy kanale YouTube.

\footnotetext{
${ }^{3}$ Narzędzie dostępne jest pod adresem: www.napoleoncat.com (po wykupieniu dostępu).

4 Ogólne informacje na temat SII dostępne są w artykule: O. Berezowski, Social Interaction Index 2, https://napoleoncat.com/blog/social-interaction-index-2/ (dostęp: 12 listopada 2016). Informacje o wskaźniku udostępnione zostały autorce na potrzeby opracowania badań po wykupieniu dostępu do platformy NapoleonCat. Dostępne w zbiorach autorki.
} 
Twitter jako jedyny kanał społecznościowy, w którym aktywny był Donald Tusk w okresie kampanii wyborczej do europarlamentu, nie dostarcza informacji na temat zbliżających się wyborów. Polityk zamieścił na nim 16 wpisów. Tylko jeden z nich bezpośrednio dotyczył działalności partii i wyborów do PE. Był to wpis zachęcający do obejrzenia klipu wyborczego PO Człowiek Europy ${ }^{5}$.

W okresie kampanii wyborczej przed wyborami samorządowymi Donald Tusk był jeszcze mniej aktywny — na Twitterze zamieścił tylko 3 wpisy, z których żaden nie był związany z działalnością partii i wyborami samorządowymi.

\section{Ewa Kopacz}

Obecność Ewy Kopacz w Internecie jest większa niż Donalda Tuska. Nie posiada ona własnej witryny internetowej, a domena kopacz.pl, która obecnie nie jest aktywna, w okresie 2014-2015 przekierowywała do strony www.marszalek.sejm.pl.

Ewa Kopacz komunikowała się z wyborcami za pomocą jednego, niezwiązanego z funkcją partyjną oraz stanowiskiem premiera, kanału - profilu na Facebooku. Choć jej profil istnieje od 2011 r., aktywność Kopacz na nim była bardzo niska. Trwała do września 2014, następnie została wznowiona w sierpniu 2015, gdy trwała już kampania wyborcza do parlamentu. Należy dodać, że Ewa Kopacz ma obecnie profil na Twitterze, za pomocą którego komunikuje się z wyborcami, założyła go jednak dopiero 25 stycznia 2016, już po przejściu PO do opozycji i stracie stanowiska zarówno premiera, jak i lidera partii (przestała pełnić tę funkcję 26 października 2016).

Jedyny materiał umożliwiający analizę komunikacji Ewy Kopacz w Internecie jako lidera to wpisy zamieszczane na jej fanpage'u w okresie kampanii wyborczej do parlamentu. W jej trakcie na profilu Ewy Kopacz zostało zamieszczonych 136 wpisów, co daje średnio 2 wpisy dziennie. Na każdy z wpisów przypadały średnio 122 komentarze oraz 896 polubień. Średni indeks SII wyniósł w tym okresie 270. Wpisy zawierały dodatkowe elementy (najczęściej zdjęcia ilustrujące treść wpisu) i dotyczyły dwóch tematów — relacjonowały przebieg kampanii wyborczej, w szczególności przebieg podróży Ewy Kopacz po Polsce, oraz oficjalnych wydarzeń, w których polityk brała udział z racji pełnienia funkcji premiera.

Szczególnie istotny jest fakt, że intensywna komunikacja Kopacz na Facebooku zakończyła się wraz z dniem wyborów. Przez kolejne dwa miesiące, do końca 2015 r., na profilu ukazało się zaledwie 19 postów, a indeks SII spadł z 270 do 105. W skazuje to bardzo jasno na charakter i cel komunikacji na fanpage’u Ewy Kopacz - miała ona jedynie charakter chwilowy, stricte wyborczy, i nastawiona była na promocję.

W przypadku komunikacji internetowej zarówno Donalda Tuska, jak i Ewy Kopacz należy wziąć pod uwagę również fakt, że do dyspozycji mieli oni dodatkowo kanały komunikacji internetowej Kancelarii Prezesa Rady Ministrów (KPRM), w szczególności fanpage na Facebooku, na którym występuje największy stopień interakcji z obywatelem, w tym przypadku postrzeganym również jako wyborca. Choć przekazy zamieszczane tam w okresie kampanii parlamentarnej nie miały charakteru bezpośrednio wy-

\footnotetext{
${ }^{5}$ www.twitter.com/donaldtusk/status/464084067500457984 (dostęp: 12 grudnia 2016).
} 
borczego, prezentowały osiągnięcia rządu Ewy Kopacz, co było elementem kreowania pozytywnego wizerunku partii, której była liderem, a także jej samej. W analizowanym okresie na fanpage’u KPRM zamieszczono 145 wpisów. Oficjalne kanały komunikacji KPRM, tak jak cała administracja publiczna, obowiązuje zasada apartyjności i apolityczności, nie można więc ich traktować jako kanałów komunikacji wyborczej. W świetle badania komunikacji liderów politycznych czy partii politycznych nie można jednak ich ignorować - są ważnym sposobem dotarcia do wyborców. Analiza ta wykracza jednak poza zakres niniejszego opracowania ${ }^{6}$.

Indywidualna komunikacja liderów PO w trakcie cyklu wyborczego w latach 20142015 nie odgrywała istotnej roli w strategii wyborczej partii. Pokazują to wyraźnie statystki dotyczące komunikacji PO w okresie analizowanych kampanii wyborczych.

Tabela 1 prezentuje dane liczbowe ilustrujące intensywność komunikacji politycznej PO i porównuje je z danymi liczbowymi odnośnie do komunikacji lidera partii w danym okresie. Znikoma komunikacja lidera (Donald Tusk) w okresie wyborów do PE i wyborów samorządowych z 2014 r. ograniczona była do wpisów na Twitterze. W okresie kampanii prezydenckiej Ewa Kopacz, ówczesny lider partii, nie prowadziła komunikacji w mediach społecznościowych. Dołączenie do analizy komunikacji internetowej w tym okresie Bronisława Komorowskiego, kandydata popieranego przez PO, nie byłoby właściwe z uwagi na przyjętą kategoryzację badań — analizie podlega komunikacja wyłącznie liderów, a nie kandydatów wystawionych na listy wyborcze lub, jak w tym przypadku, popieranych przez partie polityczne. Zatem porównanie komunikacji lidera i jego partii możliwe jest tylko w odniesieniu do fanpage’a Ewy Kopacz w okresie kampanii

Tabela 1. Liczba postów i wskaźnik SII w komunikacji Platformy Obywatelskiej oraz lidera partii na Facebooku w latach 2014-2015.

\begin{tabular}{|c|c|c|c|c|c|}
\hline & \multirow{2}{*}{\multicolumn{2}{|c|}{$\mathrm{PO}$}} & & \\
\hline & & & & \multicolumn{2}{|c|}{ Lider PO } \\
\hline $\begin{array}{c}\text { wybory, } \\
\text { których dotyczy } \\
\text { kampania }\end{array}$ & $\begin{array}{l}\text { przedział } \\
\text { czasowy }\end{array}$ & $\begin{array}{c}\text { liczba } \\
\text { zamieszczonych } \\
\text { postów }\end{array}$ & $\begin{array}{l}\text { wskaźnik } \\
\text { SII }\end{array}$ & $\begin{array}{c}\text { liczba } \\
\text { zamieszczonych } \\
\text { postów }\end{array}$ & wskaźnik SII \\
\hline wybory do PE & luty-maj 2014 & 197 & $\begin{array}{l}\text { brak } \\
\text { danych }\end{array}$ & brak komunikacji & $\begin{array}{c}\text { brak } \\
\text { komunikacji }\end{array}$ \\
\hline $\begin{array}{l}\text { wybory } \\
\text { samorządowe }\end{array}$ & $\begin{array}{c}\text { sierpień-listopad } \\
2014\end{array}$ & 203 & 419,45 & brak komunikacji & $\begin{array}{c}\text { brak } \\
\text { komunikacji }\end{array}$ \\
\hline $\begin{array}{l}\text { wybory } \\
\text { prezydenckie }\end{array}$ & luty-maj 2015 & 192 & 478,4 & brak komunikacji & $\begin{array}{c}\text { brak } \\
\text { komunikacji }\end{array}$ \\
\hline $\begin{array}{l}\text { wybory } \\
\text { parlamentarne }\end{array}$ & $\begin{array}{c}\text { lipiec-październik } \\
2015\end{array}$ & 295 & 649,95 & 156 & 270,2 \\
\hline
\end{tabular}

Źródło: opracowanie własne na podstawie danych z NapoleonCat.

${ }^{6}$ Analizę komunikacji KPRM w okresie kampanii wyborczej przed wyborami parlamentarnymi z 2015 r. zawiera artykuł Komunikacja Kancelarii Prezesa Rady Ministrów w mediach społecznościowych w okresie zmiany władzy. Dostępny jest on w zbiorach prywatnych autorki. 
przed wyborami parlamentarnymi. Różnica jest duża. Na profilu partii zamieszczono 275 wpisów, a u Ewy Kopacz 136. Wskaźnik SII w przypadku PO był ponaddwukrotnie wyższy niż na profilu Ewy Kopacz $(270,2)$ i wyniósł 649,95 . Dane te pokazują, iż internetowa komunikacja partii politycznej w okresie wyborów nie jest nastawiona na personalizację przekazu poprzez osobę lidera - głównym aktorem komunikującym się $\mathrm{z}$ wyborcą jest partia.

\section{Prawo i Sprawiedliwość}

Za lidera Prawa i Sprawiedliwości bezsprzecznie uznawany jest Jarosław Kaczyński, prezes partii od 2003 r. Jego aktywność internetowa sprowadza się do krótkiej aktywności na Twitterze, która nie miała jednak charakteru bezpośredniego. W 2010 r., w trakcie kampanii prezydenckiej, prowadzony był serwis informacyjny www.jkaczynski.info i powiązane z nim konto na Twitterze (@jkaczynski.info).

Cała komunikacja partii w Internecie nakierowana była na oficjalne kanały partyjne (m.in. Facebook, Twitter, YouTube, Instagram). W trakcie wyborów prezydenckich aktywne były także kanały Andrzeja Dudy (szczególnie jego konto na Facebooku oraz Twitterze), natomiast $w$ trakcie wyborów parlamentarnych - Beaty Szydło. Żaden z tych polityków nie jest i nie był wtedy postrzegany jako rzeczywisty lider partii, jedynie jako reprezentant w wyborach, stąd analiza ich aktywności w mediach społecznościowych i porównanie z liderami pozostałych ugrupowań nie jest właściwym przedmiotem niniejszej analizy.

Warto jednak, choćby skrótowo, przytoczyć dane porównujące aktywność partii w Internecie oraz kandydatów uważanych $\mathrm{w}$ danym okresie za „twarz” partii. W trakcie wyborów samorządowych późniejsze lokomotywy wyborcze, czyli Andrzej Duda i Beata Szydło, nie były aktywne, prym w komunikacji, m.in. na Facebooku, portalu, na którym najlepiej widać to zróżnicowanie, wiodła partia. Sytuacja ta zmieniła się wraz z nadejściem kampanii wyborczej - prezydenckiej i parlamentarnej. Zdecydowanie intensywniejsza, zarówno pod kątem liczby publikowanych przekazów, jak i aktywności internautów, stała się komunikacja głównego kandydata w danej elekcji. Dotyczy to szczególnie Andrzeja Dudy. Dane zaprezentowane w tabeli 2 wskazują na to, iż kampania prezydencka kandydata PiS była silnie spersonalizowana, uwaga wyborców była nakierowana indywidualnie na kandydata, nie na partię. W przypadku Beaty Szydło i wyborów parlamentarnych polaryzacja ta nie była już tak silnie widoczna. Więcej treści zaprezentowała partia, jednak to posty z profilu kandydatki na premiera bardziej angażowały wyborców. W całym tym procesie żadnej roli nie odgrywał Jarosław Kaczyński, lider partii.

Przypadek PiS jest przykładem prowadzenia kampanii wyborczej silnie zorientowanej na kandydata, który jest przeciwwagą dla lidera partii politycznej. W przypadku PiS kontrast ten jest o tyle ciekawy, że lider Jarosław Kaczyński prezentuje tradycyjne wartości i tradycyjny sposób komunikowania się z wyborcami, podczas gdy Beata Szydło, a szczególnie Andrzej Duda, kreują się na polityków bardziej nowoczesnych. 
Tabela 2. Liczba postów i wskaźnik SII w komunikacji Prawa i Sprawiedliwości oraz lokomotyw wyborczych partii na Facebooku w latach 2014-2015.

\begin{tabular}{l|c|c|c|c|c|c|c}
\cline { 3 - 8 } & \multicolumn{2}{c}{ PiS } & \multicolumn{2}{c|}{ Andrzej Duda } & \multicolumn{2}{c}{ Beata Szydło } \\
\hline $\begin{array}{c}\text { których dotyczy } \\
\text { kampania }\end{array}$ & $\begin{array}{c}\text { przedział } \\
\text { czasowy }\end{array}$ & $\begin{array}{c}\text { liczba } \\
\text { postów }\end{array}$ & $\begin{array}{c}\text { wskaźnik } \\
\text { SII }\end{array}$ & $\begin{array}{c}\text { liczba } \\
\text { postów }\end{array}$ & $\begin{array}{c}\text { wskaźnik } \\
\text { SII }\end{array}$ & $\begin{array}{c}\text { liczba } \\
\text { postów }\end{array}$ & $\begin{array}{c}\text { wskaźnik } \\
\text { SII }\end{array}$ \\
\hline wybory do PE & luty-maj 2014 & 190 & $\begin{array}{c}\text { brak } \\
\text { danych }\end{array}$ & 84 & brak danych & 6 & $\begin{array}{c}\text { brak } \\
\text { danych }\end{array}$ \\
\hline $\begin{array}{l}\text { wybory } \\
\text { samorządowe }\end{array}$ & $\begin{array}{c}\text { sierpień-listopad } \\
2014\end{array}$ & 287 & 291,6 & 26 & 22,84 & 3 & 0,06 \\
\hline $\begin{array}{l}\text { wybory } \\
\text { prezydenckie }\end{array}$ & luty-maj 2015 & 59 & 134,8 & 418 & 1295,1 & 14 & 2,25 \\
\hline $\begin{array}{l}\text { wybory } \\
\text { parlamentarne }\end{array}$ & $\begin{array}{c}\text { lipiec-październik } \\
2015\end{array}$ & 334 & 735,65 & 269 & 1371,9 & 371 & 674,93 \\
\hline
\end{tabular}

Źródło: opracowanie własne na podstawie danych z NapoleonCat.

\section{Polskie Stronnictwo Ludowe}

Janusz Piechociński był liderem Polskiego Stronnictwa Ludowego od listopada 2012 do listopada 2015 r., gdy po niekorzystnym wyniku wyborczym dla PSL oraz dla samego Piechocińskiego, który nie uzyskał ponownie mandatu poselskiego, na stanowisku prezesa PSL zastąpił go Władysław Kosiniak-Kamysz.

Janusz Piechociński to polityk aktywny w mediach społecznościowych, obecny na Facebooku $^{7}$ i Twitterze ${ }^{8}$, oraz autor blogu ${ }^{9}$. Jego komunikacja we wszystkich kanałach jest intensywna, są one codziennie, a nawet kilka razy dziennie aktualizowane. W każdym $z$ analizowanych okresów Janusz Piechociński zamieszczał podobnego rodzaju wpisy. Odwoływał się do swojej pracy, komentował bieżące wydarzenia z kraju, odnosił się również do kampanii PSL prowadzonej w mediach społecznościowych, co przedstawia tabela 3.

W przypadku Janusza Piechocińskiego szczególną uwagę należy zwrócić na jego komunikację na Twitterze. Jej intensywność i różnorodność stała się przedmiotem internetowych żartów i memów ${ }^{10}$. Powstał nawet fanpage „Mądrości z twittera Janusza Piechocińskiego" ${ }^{11}$ podkreślający (bez ataku politycznego) trywialność wpisów polityka i ich nieużyteczność dla odbiorcy. Przykład tego fanpagea to oczywiście żartobliwa charakterystyka sposobu prowadzenia komunikacji przez Piechocińskiego.

\footnotetext{
${ }^{7}$ www.facebook.com/piechocinskijanusz.

8 www.twitter.com/Piechocinski.

9 www.piechocinski.blog.onet.pl.

${ }^{10}$ Więcej o zjawisku memów: M. Zaremba, Memy internetowe (2010-2011), „Media i Społeczeństwo”

11 www.facebook.com/twitterpiechocinski.
} 2012, nr 2. 
Tabela 3. Liczba postów i wskaźnik SII w komunikacji Polskiego Stronnictwa Ludowego i Janusza Piechocińskiego na Facebooku w latach 2014-2015.

\begin{tabular}{l|c|c|c|c|c}
\cline { 3 - 5 } \multicolumn{2}{c}{} & \multicolumn{2}{c|}{ PSL } & \multicolumn{2}{c}{ Janusz Piechociński } \\
\hline $\begin{array}{c}\text { których dotyczy } \\
\text { kampania }\end{array}$ & przedział czasowy & $\begin{array}{c}\text { liczba } \\
\text { zamieszczonych } \\
\text { postów }\end{array}$ & $\begin{array}{c}\text { wskaźnik } \\
\text { SII }\end{array}$ & $\begin{array}{c}\text { liczba } \\
\text { zamieszczonych } \\
\text { postów }\end{array}$ & $\begin{array}{c}\text { wskaźnik } \\
\text { SII }\end{array}$ \\
\hline wybory do PE & luty-maj 2014 & 115 & 3 & 160 & 5 \\
\hline $\begin{array}{l}\text { wybory } \\
\text { samorządowe }\end{array}$ & $\begin{array}{c}\text { sierpień-listopad } \\
2014\end{array}$ & 315 & 4 & 123 & 4 \\
\hline $\begin{array}{l}\text { wybory } \\
\text { prezydenckie }\end{array}$ & luty-maj 2015 & 1220 & 11 & 148 & 3 \\
\hline $\begin{array}{l}\text { wybory } \\
\text { parlamentarne }\end{array}$ & $\begin{array}{c}\text { lipiec-październik } \\
2015\end{array}$ & 734 & 38 & 115 & 15 \\
\hline
\end{tabular}

Źródło: opracowanie własne na podstawie danych z NapoleonCat.

Swoje konto na Twitterze założył on w czerwcu 2011 r. Do listopada 2016 r. opublikował aż 18,5 tysiąca wpisów, co daje średnio 10 wpisów dziennie. Również w trakcie elekcji komunikacja ta była niezwykle intensywna. W okresie kampanii przed wyborami do PE zamieścił on 693 wpisy, przed samorządowymi -712 , przed prezydenckimi -663 , a przed parlamentarnymi - 536. Można więc stwierdzić, że intensywność komunikacji jest na stałym poziomie. Wpisy dotyczą nie tylko kampanii i popieranych kandydatów (głównie w przypadku kampanii prezydenckiej i kandydata PSL na prezydenta - Adama Jarubasa), ale szerokiego spektrum zagadnień gospodarczych, społecznych, politycznych, popkulturowych czy sportowych. To luźne wpisy, np. z wynikami badań CBOS, kursami walut, linkami do artykułów opisujących bieżące wydarzenia w kraju i na świecie. Można jednak stwierdzić, że dominująca tematyka to kwestie dotyczące gospodarki, rolnictwa i turystyki.

Blog Janusza Piechocińskiego jest na tyle obszernym materiałem, iż jego analiza mogłaby stanowić odrębne badanie. Prowadzony od marca 2009 r. jest jednym z najstarszych blogów liderów polskiej sceny politycznej. Nadal jest często aktualizowany. Polityk publikuje zarówno własne opinie, jak i informacje o wydarzeniach, fragmenty wypowiedzi medialnych.

Janusz Piechociński jest niezwykle aktywny w mediach społecznościowych, podobnie jak jego partia, choć to ona wchodzi w większą interakcję z wyborcą. Ogromna liczba przekazów generowanych przez polityka nie powoduje równie wysokiego zaangażowania internautów w dyskusję. Polityk w swojej społecznościowej komunikacji silnie identyfikuje się z partią i nawiązuje do tematyki przez nią poruszanej, choć agitacja wyborcza nie była jego dominującym celem komunikacyjnym. 


\section{Sojusz Lewicy Demokratycznej}

Przez cały analizowany okres liderem Sojuszu Lewicy Demokratycznej był Leszek Miller. Na przewodniczącego partii wybrany został w grudniu 2011 r., a swoją ostatnią kadencję zakończył w styczniu 2016 r., gdy po całkowitej porażce SLD w wyborach parlamentarnych i prezydenckich nie ubiegał się o ponowny wybór, a stery w partii przejął Włodzimierz Czarzasty.

Internetowa aktywność Leszka Millera jest nieco chaotyczna i prowadzona w kilku kanałach internetowych. Polityk posiada fanpage ${ }^{12}$, profil na Twitterze ${ }^{13}, \operatorname{blog}^{14}$. Publiczny (pod kątem możliwości wglądu w zamieszczane treści) jest również jego prywatny profil na Facebooku.

Leszek Miller swój profil na Twitterze prowadzi od 2012 r. Jest na nim bardzo aktywny, gdyż na przestrzeni 4 lat zamieścił aż 6 tysięcy wpisów. Twittera używa głównie do informowania o swojej działalności politycznej - publikuje komentarze do bieżących wydarzeń w kraju i na świecie, informacje o wydarzeniach, w których bierze udział, wypowiedziach medialnych innych polityków, retweetuje (czyli podaje dalej) posty osób publicznych, mediów i innych instytucji publicznych dotyczące działalności jego i SLD.

W okresie trwania kampanii wyborczej do PE na Twitterze Leszka Millera ukazały się 603 wpisy ('średnio 3 dziennie). Dotyczyły głównie bieżących wydarzeń w Polsce oraz stanowiły odniesienie do wypowiedzi polityków innych opcji politycznych i dziennikarzy, jakie padały w tym okresie. Polityk wielokrotnie zamieszczał informacje i odniesienia dotyczące bezpośrednio SLD (a właściwie koalicji wyborczej SLD-UP) i prowadzonej kampanii wyborczej. Należy jednak podkreślić, iż tweety komponowane były tak, że bardziej niż sama partia i kampania uwypuklona była tematyka aktualnej sytuacji w Unii Europejskiej i postrzeganie UE w Polsce. Polityk przypominał często swoje osiągnięcia w zakresie wprowadzenia Polski do UE, szczególnie negocjacje i podpisanie traktatu akcesyjnego.

W okresie wyborów samorządowych, w których SLD startował jako koalicja SLD Lewica-Razem ${ }^{15}$, Leszek Miller na swoim Twitterze skupiał się na relacjonowaniu spotkań z wyborcami, komentowaniu aktualnych wydarzeń w Polsce i zamieszczaniu informacji o przebiegu kampanii SLD. Zamieścił 551 wpisów (średnio 6 dziennie). Wykazał więc większą aktywność niż w trakcie trwania kampanii przed wyborami do PE.

Komunikacja Millera na Twitterze w trakcie kampanii wyborczej przed wyborami prezydenckimi była również bardzo intensywna. Średnio zamieszczał 8 wpisów dziennie (935 tweetów w analizowanym okresie kampanii wyborczej przed wyborami prezydenckimi). Silnie wspierały one partię, podkreślając program kandydatki SLD Magdaleny Ogórek oraz informując o kolejnych etapach i wydarzeniach z przebiegu jej kampanii.

\footnotetext{
12 www.facebook.com/Leszek.Miller.LM.

13 www.twitter.com/leszekmiller.

14 www.leszek-miller.blog.onet.pl.

15 Oprócz SLD w skład koalicyjnego komitetu wyborczego wchodziły także Unia Pracy oraz Krajowa Partia Emerytów i Rencistów.
} 
W trakcie kampanii przed wyborami parlamentarnymi rola Leszka Millera zmieniła się. Nadal był liderem SLD, jednak partia startowała w wyborach w koalicji Zjednoczonej Lewicy, dla której został wyłoniony nowy lider - Barbara Nowacka. Mimo to komunikacja Millera na Twitterze była na podobnym poziomie intensywności (723 tweety, czyli około 8 dziennie). Zbliżona była również tematyka - polityk podkreślał pomysły koalicji, relacjonował kampanię wyborczą, komentował bieżące kwestie.

O ile komunikacja Leszka Millera jest na Twitterze czytelna - ma linię przewodnią, komunikaty konstruowane są podobnie, wykorzystywane są różne możliwości portalu, o tyle jego komunikacja na Facebooku jest o wiele bardziej chaotyczna. Polityk posiada fanpage na Facebooku oraz prywatny, lecz ogólnodostępny profil użytkownika portalu. Z punktu widzenia analizy komunikacji lidera istotniejsze byłoby przeanalizowanie prywatnego profilu polityka, jednak to nie on służy komunikacji ze społecznością, więc jego analiza nie byłaby poprawna. Parametry fanpage’a i profilu prywatnego różnią się też na tyle, że nie jest możliwe ich porównanie. Na fanpage’u lider nie komunikuje się w pierwszej osobie. Udostępniane są tam jedynie informacje z mediów na temat działalności Leszka Millera, teksty opublikowane na stronie internetowej SLD lub też wpisy z prywatnego profilu Leszka Millera. Zamieszczanych wpisów jest mniej niż na Twitterze, lecz nadal dużo (aż do maja 2015 r., kiedy to zaprzestano prowadzenia profilu). Niska jest również aktywność internautów - nie wdają się oni w dyskusję z politykiem, on też nie wchodzi z nimi w interakcję. SII w analizowanym okresie waha się pomiędzy 3 a 15 punktów (średnio 9). To mało w stosunku do wartości wskaźnika SII samej partii SLD, który w okresach kampanii wyniósł średnio 143.

Tabela 4. Liczba postów i wskaźnik SII w komunikacji Leszka Millera oraz Sojuszu Lewicy Demokratycznej na Facebooku w latach 2014-2015.

\begin{tabular}{l|c|c|c|c|c}
\cline { 3 - 5 } \multicolumn{2}{c}{} & \multicolumn{2}{c|}{ SLD } & \multicolumn{2}{c}{ Leszek Miller } \\
\hline $\begin{array}{c}\text { wtórych dotyczy } \\
\text { kampania }\end{array}$ & przedział czasowy & $\begin{array}{c}\text { liczba } \\
\text { zamieszczonych } \\
\text { postów }\end{array}$ & wskaźnik SII & $\begin{array}{c}\text { liczba } \\
\text { zamieszczonych } \\
\text { postów }\end{array}$ & wskaźnik SII \\
\hline wybory do PE & luty-maj 2014 & 1320 & $\begin{array}{c}\text { brak } \\
\text { danych }\end{array}$ & 151 & 3 \\
\hline $\begin{array}{l}\text { wybory } \\
\text { samorządowe }\end{array}$ & lipiec-listopad 2014 & 568 & 166 & 131 & 9 \\
\hline $\begin{array}{l}\text { wybory } \\
\text { prezydenckie }\end{array}$ & luty-maj 2015 & 582 & 194 & 108 & 15 \\
\hline $\begin{array}{l}\text { wybory } \\
\text { parlamentarne }\end{array}$ & $\begin{array}{c}\text { lipiec-październik } \\
2015\end{array}$ & 291 & 79 & $\begin{array}{c}\text { brak } \\
\text { komunikacji }\end{array}$ & $\begin{array}{c}\text { brak } \\
\text { komunikacji }\end{array}$ \\
\hline
\end{tabular}

Źródło: opracowanie własne na podstawie danych z NapoleonCat.

Leszek Miller prowadzi również blog na platformie blog.pl (dawniej blog.onet.pl). Pierwszy wpis na nim pojawił się we wrześniu 2007 r. Co ciekawe, o ile przez lata wpisy pojawiały się z różną częstotliwością, lecz systematycznie, o tyle w okresie kampanii do 
PE opublikowany został tylko jeden wpis w formie listu do wyborców wzywającego do głosowania na SLD-UP ${ }^{16}$. W okresie kampanii przed wyborami samorządowymi pojawiło się 5 wpisów, ale żaden $\mathrm{z}$ nich nie był związany $\mathrm{z}$ wyborami i partią. W przypadku kampanii wyborczej przed wyborami prezydenckimi pojawiły się 4 wpisy, w tym jeden związany bezpośrednio z kampanią i oceną kandydatury Magdaleny Ogórek. W przypadku wyborów parlamentarnych, w trakcie kampanii ją poprzedzającej, nie pojawił się żaden wpis na blogu. Można więc stwierdzić, że jest on dla Leszka Millera platformą publicystyczną, nie wyborczą.

Podsumowując komunikację Leszka Millera w mediach społecznościowych, należy podkreślić, że SLD jako partia używa o wiele większej liczby kanałów komunikacji internetowej - posiada zarówno fanpage, jak i kanał na YouTube, konto na Instagramie i Pintereście. Analizując komunikację partii w sieci, można uznać, iż jej lider jest mniej widoczny w Internecie niż sama partia, choć, co ważne, chętnie publikuje własne przemyślenia niekłócące się z linią komunikacyjną partii.

\section{KORWiN (Kongres Nowej Prawicy)}

Kolejnym z liderów, których komunikację internetową poddano analizie, jest Janusz Korwin-Mikke, lider Kongresu Nowej Prawicy (w okresie kampanii przed wyborami samorządowymi i do PE) oraz Wolności, znanej pod skrótową nazwą KORWiN. Janusz Korwin-Mikke jest zdecydowanie najpopularniejszym politykiem w mediach społecznościowych. Potwierdzają to kolejne, comiesięczne raporty Fanpage Trends wydawane przez Sotrender. Przykładowo, we wrześniu 2015 r. jego fanpage ${ }^{17}$ śledziło ponad 665 tysięcy osób ${ }^{18}$. Również partie $\mathrm{z}$ nim związane znajdowały się $\mathrm{w}$ tym okresie $\mathrm{w}$ czołówce zestawienia najpopularniejszych (czyli posiadających największą liczbę fanów) partii politycznych na Facebooku. Wzrost popularności Kongresu Nowej Prawicy w mediach społecznościowych zamienił się w spadek w momencie odejścia dotychczasowego lidera. Partia KORWiN przebiła ją natomiast liczbą polubień strony, będących wyrazem popularności na Facebooku, w bardzo krótkim czasie swojego istnienia. Relacje między tymi profilami mogą być przedmiotem odrębnej analizy, tutaj kwestia ta jest jedynie sygnalizowana ${ }^{19}$. Fenomen popularności zarówno Janusza Korwina-Mikkego, jak i jego partii politycznych w mediach społecznościowych, a jednocześnie niemożność przekroczenia przez ugrupowanie progu wyborczego, to szerokie i warte dokładnej analizy zagadnienie.

Sam sposób komunikowania Janusza Korwina-Mikkego w Internecie i mediach społecznościowych jest bardzo charakterystyczny. Swoje konta posiada on na Twitterze i Facebooku. Prowadzi również autorski blog 20 - oraz własną witrynę internetową, na

\footnotetext{
16 www.leszek-miller.blog.onet.pl/2014/05/.

17 www.facebook.com/janusz.korwin.mikke.

18 Fanpage Trends, https://www.sotrender.com/pl/trends/facebook/reports/201509/politycy\#trends (dostęp: 12 listopada 2016).

${ }^{19}$ Szersze wyjaśnienie znaleźć można w raportach Fanpage Trends wydawanych przez Sotrender.

20 www.korwin-mikke.blog.onet.pl.
} 
której dostępne jest forum oraz księgarnia internetowa oferująca pozycje polecane przez polityka. W Internecie Janusz Korwin-Mikke jest na swój sposób instytucją, politykiem o usystematyzowanym gronie odbiorców, zdającym sobie sprawę nie tylko z konieczności, ale i potencjału komunikacji internetowej.

Janusz Korwin-Mikke nie prowadzi bardzo intensywnej komunikacji na Twitterze. Ma tam dwa konta. Na pierwszym z nich był aktywny do lutego $2014 \mathrm{r}^{21}{ }^{21}$ Kolejne konto ${ }^{22}$ założył, nie kasując poprzedniego, w listopadzie tego samego roku i od tego czasu za jego pomocą komunikuje się z internautami. Luka czasowa w komunikacji na Twitterze pozwala na analizę tylko wycinka komunikacji tego lidera w tym medium w okresie kampanii przed wyborami parlamentarnymi. W lutym 2014 r. Korwin-Mikke zamieścił na Twitterze 72 wpisy. Dotyczyły one jego aktywności - spotkań z wyborcami, wywiadów. W późniejszym okresie jego aktywność w tym kanale spadła. W czasie kampanii przed wyborami prezydenckimi na swoim profilu zamieścił 45 wpisów, które w zdecydowanej większości dotyczyły prowadzonej kampanii - informowały o spotkaniach i wypowiedziach w mediach - udziału w debatach i dyskusjach oraz sondażowych wyników. W okresie kampanii przed wyborami parlamentarnymi na profilu polityka ukazało się tylko 29 wpisów. W zdecydowanej większości były one komentarzami do bieżącej sytuacji i wydarzeń w kraju oraz odniesieniami do trwającej kampanii wyborczej — były to np. oceny debaty przedwyborczej, sondaży przedwyborczych.

Tabela 5. Liczba postów i wskaźnik SII w komunikacji Janusza Korwina-Mikkego oraz Kongresu Nowej Prawicy i partii KORWiN na Facebooku w latach 2014-2015.

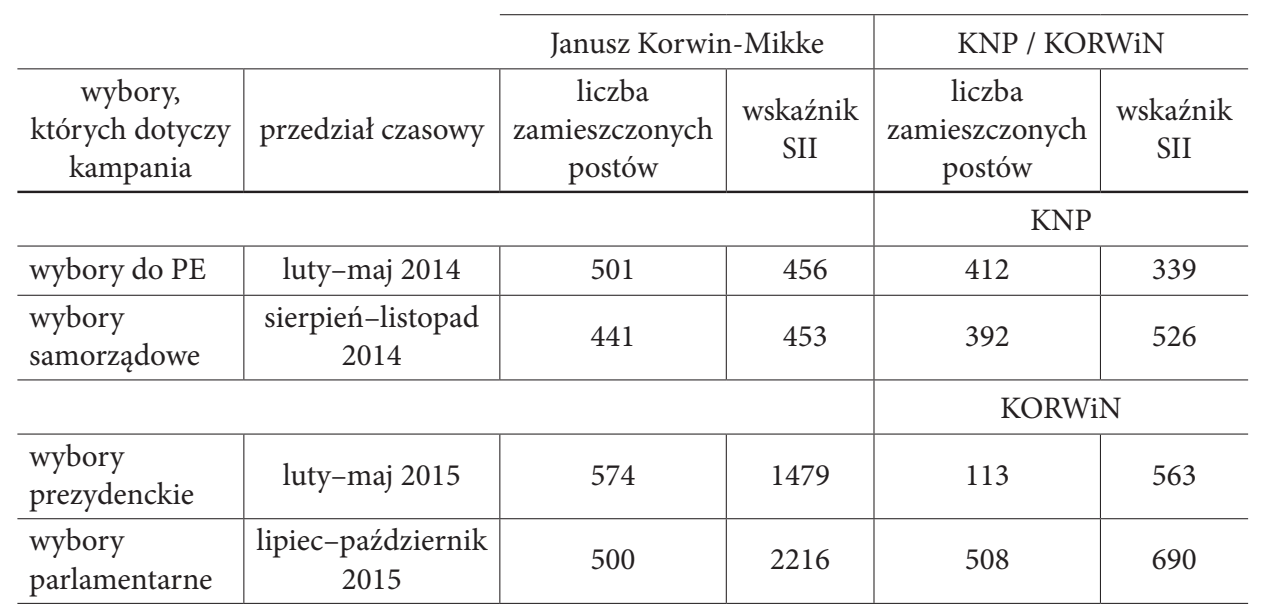

Źródło: opracowanie własne na podstawie danych z NapoleonCat.

21 www.twitter.com/korwinmikke.

22 www.twitter.com/jkmmikke. 
Komunikacja najpopularniejszego, pod kątem liczby polubień, lidera partii politycznej i polityka w Polsce ${ }^{23}$ na Facebooku cechuje się również najwyższym stopniem interakcji z internautami. Komunikacja Janusza Korwina-Mikkego, niezależnie od trwającej aktualnie kampanii wyborczej, ma ten sam charakter. W sposób, który może być uznawany za satyryczny, ironiczny czy nawet oburzający, komentuje on bieżące sprawy z kraju i świata, wyrażając swoje poglądy często w sposób obrazkowy. Nierzadko pojawia się w nich krytyka i wyśmiewanie przeciwników politycznych.

Wysoki poziom interakcji z internautami, zarówno polityka, jak i partii, na czele których stoi, może być bezpośrednio związany z wyrazistym i bezpośrednim charakterem informacji zamieszczanych przez Janusza Korwina-Mikkego na Facebooku. Odwołuje się on do spraw bardzo wyrazistych i kontrowersyjnych, przez co budzących rozbudowaną dyskusję pod wpisami. Przykładowe tematy to kwestia przyjmowania uchodźców, krytyka obecnej władzy, krytyka działalności UE. Janusz Korwin-Mikke poprzez bezpośredniość swoich wpisów i poruszanie konkretnych wartości skupia wokół siebie grupę osób o określonych poglądach. Jego profil stanowi dla nich niejako platformę do dyskusji. Może być to uznane za jedną z przyczyn tak dużej jego popularności.

\section{Nowe partie polityczne w wyborach parlamentarnych 2015 r.: Partia Razem, Nowoczesna, Kukiz'15}

W kontekście kampanii przed wyborami parlamentarnymi z 2015 r. należy również przeanalizować komunikację nowych aktorów na scenie politycznej, którzy niemal od początku swej działalności zajęli na niej ważne miejsce. Są to: Partia Razem, Nowoczesna z Ryszardem Petru i Kukiz'15 z Pawłem Kukizem, który startował również w wyborach prezydenckich.

Analiza komunikacji lidera Partii Razem jest o tyle trudna, iż partia ta deklaruje brak jednego lidera. Partią kieruje dziewięcioosobowy Zarząd Krajowy. Nie ma w nim funkcji prezesa lub przewodniczącego. W trakcie kampanii wyborczej na nieformalnego lidera ugrupowania wyrósł Adrian Zandberg. Z punktu widzenia analizy niniejszej pracy wzięcie go pod uwagę nie będzie poprawne, dlatego też analiza lidera tej partii zostanie pominięta.

Lider Nowoczesnej, Ryszard Petru, komunikuje się zarówno za pomocą Twittera ${ }^{24}$, jak i Facebooka ${ }^{25}$. W obu kanałach był bardzo aktywny. Na Twitterze w trakcie kampanii wyborczej przed wyborami parlamentarnymi zamieścił aż 1141 wpisów. W większości można uznać je za komentarze do obecnej sytuacji w kraju, działań konkurentów politycznych i przebiegu kampanii. Bardzo często informował też (retweetując wpisy z profilu swojej partii) o kolejnych działaniach podejmowanych przez Nowoczesną w trakcie kampanii wyborczej.

${ }^{23}$ Politycy i partie, Fanpage Trends, https://www.sotrender.com/pl/trends/facebook/reports/201509/politycy\#trends (dostęp: 12 grudnia 2016).

24 www.twitter.com/ryszardpetru.

25 www.facebook.com/PetruRyszard. 
Na Facebooku Ryszard Petru komunikował intensywnie, ale nie zamieszczał nadmiaru informacji. Średnio na jego profilu ukazywał się 1 post dziennie, co jest zgodne ze „sztukąa komunikacji w mediach społecznościowych. Jego wpisy, najczęściej dotyczące propozycji Nowoczesnej, kampanii wyborczej i koniecznych według niego zmian w kraju, były bardzo popularne i angażowały wyborców. Średnie SII na jego fanpage’u w tym okresie to aż 858, podczas gdy Ewa Kopacz, ówczesna premier i lider PO, partii najbardziej zbliżonej do Nowoczesnej, której miejsce ta chciała zająć, osiągnęła SII na poziomie 247. Warto też dodać, że na fanpage’u ugrupowania aktywność internautów była mniejsza, choć zamieszczano na nim podobną liczbę wpisów. Zarówno Nowoczesna, jak i jej lider szybko stały się popularne w mediach społecznościowych — jako nowy aktor na scenie politycznej w krótkim czasie dogoniły pod względem popularności (liczby fanów) ugrupowania obecne na scenie politycznej (i w mediach społecznościowych) od lat, ale prześcignęły je pod kątem zaangażowania internautów.

Tabela 6. Liczba postów i wskaźnik SII w komunikacji Ryszarda Petru oraz partii Nowoczesna w trakcie kampanii wyborczej $2015 \mathrm{r}$.

\begin{tabular}{c|c|c|c|c|c}
\cline { 3 - 5 } \multicolumn{2}{c}{} & \multicolumn{2}{c|}{ Ryszard Petru } & \multicolumn{2}{c}{ Nowoczesna } \\
\hline $\begin{array}{c}\text { wybory, } \\
\text { których dotyczy } \\
\text { kampania }\end{array}$ & przedział czasowy & $\begin{array}{c}\text { liczba } \\
\text { zamieszczonych } \\
\text { postów }\end{array}$ & $\begin{array}{c}\text { wskaźnik } \\
\text { SII }\end{array}$ & $\begin{array}{c}\text { liczba } \\
\text { zamieszczonych } \\
\text { postów }\end{array}$ & $\begin{array}{c}\text { wskaźnik } \\
\text { SII }\end{array}$ \\
\hline $\begin{array}{c}\text { wybory } \\
\text { parlamentarne }\end{array}$ & $\begin{array}{c}\text { lipiec-październik } \\
2015\end{array}$ & 96 & 858 & 88 & 332 \\
\hline
\end{tabular}

Źródło: opracowanie własne na podstawie danych z NapoleonCat.

Paweł Kukiz to lider Ruchu Kukiz’15, początkowo ruchu społecznego, później przekształconego w stowarzyszenie. Polityk zajmuje obecnie stanowisko jego prezesa. Choć Kukiz'15 nie jest formalnie partią polityczną, z perspektywy wspomnianej już definicji wyborczej Herbuta spełnia wszelkie wymagania, by zakwalifikować je do niniejszej analizy.

Komunikacja Ruchu Kukiz'15 w Internecie to kwestia, która ze względu na rozproszenie może podlegać odrębnym badaniom - istnieje wiele lokalnych, regionalnych, fanowskich profili ruchu w mediach społecznościowych. Formalne, ogólnopolskie kanały komunikacji ugrupowania powstały dopiero po wyborach parlamentarnych ${ }^{26}$. Sam Paweł Kukiz posiada profil na Twitterze ${ }^{27}$, na którym zamieścił jednak w trakcie kampanii parlamentarnej tylko 30 wpisów. W trakcie kampanii prezydenckiej nie komunikował się za jego pomocą. Zamieszczane wpisy w większości dotyczyły przebiegu kampanii wyborczej Ruchu Kukiz'15.

Paweł Kukiz był o wiele bardziej aktywny i popularny na Facebooku ${ }^{28}$. SII w okresie kampanii wyborczej wyniosło 623 (90 wpisów). Pod kątem liczby internautów śledzą-

\footnotetext{
26 www.facebook.com/pg/KlubPoselskiKukiz15/.

27 www.twitter.com/pkukiz.

28 www.facebook.com/kukizpawel.
} 
cych jego fanpage jest drugim po Januszu Korwinie-Mikkem najpopularniejszym liderem partii politycznych w Polsce. Treści, jakie zamieszczał Paweł Kukiz, skupiały się na kwestiach związanych z kampanią wyborczą i bieżącą sytuacją w kraju.

Wyrażały one konkretne poglądy związane $\mathrm{z}$ antysystemowością, $\mathrm{w}$ jej popularnym rozumieniu jako walki z obecnym układem władzy i układem partyjnym. Bezpośredniość przekazów oraz świeżość, jaką za każdym razem niesie z sobą nowy aktor na scenie politycznej, przyczyniły się do dużej aktywności internautów na fanpage’u Kukiza i jego wysokiej popularności.

\section{Podsumowanie}

Komunikacja aktorów partii politycznych w Internecie jest zagadnieniem złożonym, które poprzez ciągłe zmiany w sferze komunikacji internetowej wymaga stałego badania i analizy, zbierania i tworzenia materiałów pozwalających na komparatystykę różnych aspektów komunikowania się partii politycznych w Internecie.

Porównanie komunikacji liderów politycznych w okresie pełnego cyklu wyborczego wskazuje jednoznacznie, iż największą wagę do komunikacji z wyborcami za pomocą Internetu przywiązuje Janusz Korwin-Mikke, lider partii, która spośród 5 analizowanych odniosła najmniejsze sukcesy wyborcze w cyklu wyborczym 2014-2015.

Analiza pozwoliła na potwierdzenie postawionych hipotez badawczych. Internetowa komunikacja, szczególnie ta w mediach społecznościowych, nie ma dużego znaczenia dla liderów najważniejszych partii politycznych. Wykorzystują oni media społecznościowe mniej efektywnie niż reprezentowane przez nich partie polityczne. Liderzy najważniejszych ugrupowań politycznych - PO i PiS - nie przywiązywali do niej dużej wagi. Większe znaczenie (była intensywniejsza i budziła większe zaangażowanie internautów) miała komunikacja samej partii (widać to szczególnie w przypadku PO) lub głównych kandydatów partii, tzw. lokomotyw wyborczych. Najlepszym tego przykładem jest intensywna komunikacja w mediach internetowych Andrzeja Dudy czy Beaty Szydło - w kontraście do braku komunikacji lidera PiS Jarosława Kaczyńskiego. Liderzy partii politycznych używają najczęściej do komunikacji w mediach społecznościowych fanpage'a.

Komunikacja liderów partii politycznych w Internecie odgrywa drugorzędną rolę z punktu widzenia prowadzenia kampanii wyborczych przez ugrupowania polityczne. Mimo że liderzy polityczni najczęściej grają główną rolę pod kątem prezentowania programu partii w mediach czy na spotkaniach $\mathrm{z}$ wyborcami, nie kładzie się silnego nacisku na komunikację partii politycznych w mediach społecznościowych. Komunikacja ta pełni więc jedynie funkcję wspierającą, nie ma znaczącego wpływu na wynik wyborczy ugrupowania, niezależnie od tego, czy lider partyjny komunikuje się intensywnie w mediach społecznościowych, jak Janusz Korwin-Mikke, prowadzi komunikację niespotykającą się z dużą interakcją internautów, jak Janusz Piechociński, czy też nie prowadzi jej w ogóle, jak Jarosław Kaczyński. 
Problem badawczy, jakim jest komunikacja aktorów politycznych, wymaga stałego analizowania i zbierania danych. Dzięki temu możliwe jest porównanie różnych aspektów komunikacji internetowej. Opisane w niniejszym artykule badania to nie tylko analiza komunikacji liderów partii politycznej, ale też materiał komparatystyczny do kolejnych badań, dotyczących np. komunikacji liderów partii politycznych, które dopiero w ostatniej analizowanej tu elekcji stały się ważnymi aktorami na polskiej scenie politycznej.

\section{Bibliografia}

Berezowski O., Social Interaction Index 2, https://napoleoncat.com/blog/social-interaction-index-2/ (dostęp: 12 listopada 2016).

Bodys M., Komunikacja Kancelarii Prezesa Rady Ministrów w mediach społecznościowych w okresie zmiany $w ł a d z$, niepublikowany artykuł dostępny w zbiorach prywatnych autorki.

Cwalina W., Falkowski A., Marketing polityczny. Perspektywa psychologiczna, GWP, Gdańsk 2005.

Fanpage Trends, https://www.sotrender.com/pl/trends/facebook/reports/201509/politycy\#trends (dostęp: 12 listopada 2016).

Leksykon politologii, red. A. Antoszewski, R. Herbut, Atla2, Wrocław 2004.

Politycy i partie, Fanpage Trends, https://www.sotrender.com/pl/trends/facebook/reports/201509/politycy\# trends (dostęp: 12 grudnia 2016).

Semetko H.A., Scammell M., The SAGE Handbook of Political Communication, SAGE Publications, London 2012.

Trzeciak S., Marketing polityczny w Internecie, Muza, Warszawa 2011.

www.facebook.com/janusz.korwin.mikke.

www.facebook.com/kukizpawel.

www.facebook.com/Leszek.Miller.LM (dostęp: 12 grudnia 2016).

www.facebook.com/PetruRyszard.

www.facebook.com/pg/KlubPoselskiKukiz15/.

www.korwin-mikke.blog.onet.pl.

www.leszek-miller.blog.onet.pl (dostęp: 12 grudnia 2016).

www.napoleoncat.com (dostęp: 12 grudnia 2016).

www.piechocinski.blog.onet.pl (dostęp: 12 grudnia 2016).

www.twitter.com/donaldtusk/status/464084067500457984 (dostęp: 12 grudnia 2016).

www.twitter.com/jkmmikke.

www.twitter.com/korwinmikke.

www.twitter.com/leszekmiller (dostęp: 12 grudnia 2016).

www.twitter.com/pkukiz.

www.twitter.com/ryszardpetru.

Zaremba M., Memy internetowe (2010-2011), „Media i Społeczeństwo” 2012, nr 2. 


\section{Communication of the leaders of Polish political parties in social media during the full election cycle 2014-2015}

Keywords: social media, political leaders, political parties, election campaign

Summary

This paper presents the results of research on the communication of relevant leaders in the years 2014-2015, during the campaign period before the four elections: to the European Parliament, local, parliamentary and presidential. Quantitative and qualitative research deals with the communication of Jaroslaw Kaczynski, Donald Tusk, Ewa Kopacz, Janusz Piechocinski, Leszek Miller, Janusz Korwin-Mikke, Ryszard Petru and Paweł Kukiz. The analysis is mainly focused on communication of party leaders on Facebook and Twitter. The research described in this article is not only a political party leader's communication analysis but also a comparative material for further research into political actors' communication. 